dialect) of the Russian language', "artificial language", "the language that is not functioning in modern Ukraine", "false native language", etc. Hauling facts of political incorrectness are traced.

Discussion: We may agree that the notion "terrorism in the linguistic field" (M. Kronhaus) has become actual nowadays; "pseudolinguistics" has spread (A. Zalizniak); we may observe absolute diversity of opinions - beginning with acknowledgment of the microlanguages' status as independent to the denial of the self-reliance of the languages with old written tradition. The notion the Ukrainian language has acquired the status of ideologeme. The works in which linguopolitical issues are discussed are the texts that are written "on demand". The tutorial of O. Kamchatova and N. Nikolina is the sample of the pseudoscientific educational resource. Similar textbooks assist breeding of linguonationalism and chauvinism.

Keywords: languages of East-Slavic group, parlance, dialect, the Ukrainian language status, "terrorism in linguistic field ", "pseudolinguistics".

Vitae

Tetyana Kosmeda - Doctor of Philology (Ukraine), professor (Ukraine), titular proffesor (Poland), the head of Department of Ukrainian Studies in Adam Mickievicz University in Posnan, (Poland). Her areas of research interests include pragmalinguistics, linguoaxiology, communicative linguistics, linguistic gender studies, sociolinguistics, cognitive linguistics, linguocultural studies, phraseology, lexicography, linguistic philosophy, comparative investigation of Slavic languages.

Correspondence: tkosmeda@gmail.com

DOI 10.31558/1815-3070.2019.38.13

УДК 82-95:811.161.2'374.26

\title{
РЕЦЕНЗІЯ НА ТЕРМІНОЛОГІЧНИЙ СЛОВНИК: ЕКСПЕРТИЗА, ПРОФЕСІЙНИЙ ДІАЛОГ І НАУКОВА ДИСКУСІЯ
}

У статті йдеться про суперечки в текстах статей-відповідей на рецензї̈ на термінологічні словники, щзо мають ознаки дискусії-діалогу з поєднанням рис наукової дискусії і професійного діалогу. Доведено, щчо відповідь на критику - ие не рецензія, а публікація дискусійного характеру. Виокремлено за ознакою 'наявність / відсутність наукової дискусії, тобто наявність / відсутність відповіді на рецензію’ два жанрові типи (різновиди) рецензій на термінологічні словники: 1) рецензії, щчо отримали відповідь автора (авторів) словника; 2) рецензї, щчо не отримали відповіді автора (авторів) словника. Установлено, щзо рецензія на термінологічний словник-ие експертний висновок якості видання, а також динамічна, “жива” форма, через яку відбувається його публічне науково-критичне обговорення.

Ключові слова: наукова дискусія, професійний діалог, публікація дискусійного характеру, рецензія, статтявідповідь на рецензію, термінологічний словник, тип рецензії.

Однією з форм наукової дискусії є рецензування. Дискусії дуже важливі, оскільки в спільному обговоренні й зіткненні поглядів народжується істина. «Дискусії, як боксерський матч, цікаві та мають смисл, коли проходять між рівними за силами противниками. [...], коли М. С. Трубецькой пише Р. О. Якобсону, що не погоджується з ним стосовно довгих голосних в історії чеської мови, і на десяти сторінках аргументує свій погляд. Таке обговорення цікаве й учасникам, і далеким нащадкам» (переклад автор. - Т. П.) (Vakhtyn). Наукові дискусії в сучасній українській термінографічній критиці не стали традицією, однак вони поодиноко існують. Дискусії в текстах статей-відповідей на рецензію на словники мають ознаки не конфлікту чи суперечки, а радше дискусї-діалогу (з поєднанням рис наукової дискусії і професійного діалогу), що розуміємо як публічне обговорення особливостей репрезентування параметрів спеціального словника з висловленням зауважень експерта, його рекомендацій щодо пошуку інваріантних способів побудови словника та готовністю автора видання до прийняття критики й подальшого удосконалення словника.

Аналізу різних аспектів наукової рецензії присвячують праці українські дослідники (О. Гуманенко /Humanenko/, I. Левчук /Levchuk/, H. Mex /Mekh/, Н. Яценко /Yatsenko/та ін.) і зарубіжні науковці (X. Бергенхольц і Р. Гууз /Bergenholtz, Gouws/, Б. Степанов /Stepanov/, М. Чернишова /Chernыshova/, В. Щербін /Shcherbyn/). Вивчення рецензії на термінологічний словник як форми наукової дискусії і професійного діалогу до цього часу не здійснено, що передусім і визначає актуальність цього дослідження.

Мета статті - відстежити й проаналізувати наукові дискусії-діалоги в текстах статей-відповідей на рецензії на термінологічні словники, з'ясувати їхню теоретико-практичну значущість, а завдання - виокремити за ознакою ‘наявність / відсутність наукової дискусії, тобто наявність / відсутність відповіді на рецензію' відповідні жанрові типи (різновиди) рецензії на спеціальні видання.

Для вивчення означених проблем української термінографічної критики залучено тексти статей-відповідей (10 одиниць) на рецензії на термінологічні словники, що розміщені на сторінках значущих для наукових кіл фахових галузевих вісників, збірників і лінгвістичних періодичних видань, надрукованих протягом кінця ХІХ ст. (від 80-х рр.) - початку XXI ст. 
Сьогодні зростає інтерес до вивчення специфіки ведення наукових дискусій, тому варто більше приділяти уваги критичному субдискурсу, зокрема його жанровій формі - рецензії - як головному його репрезентанту. $\boldsymbol{P e}$ цензія є базовим жанром термінографічної критики, «вторинним текстом, у якому виклад інформації грунтується на результатах оброблення та аналізування первинного тексту термінографічного видання. Композиційні елементи рецензії підпорядковані конкретній меті: комплексно, усебічно оцінити й схарактеризувати рецензований термінологічний словник» (Petrova 211).

Для висвітлення типологічної мозаїки рецензій на фахові словники важливе значення мають публікації зарубіжних лінгвістів стосовно типів рецензій на загальномовні лексикографічні видання. Зокрема білоруський дослідник В. Щербін у статті про внесок О. Трубачова в розвиток наукової лексикографічної критики репрезентує всеохопну характеристику різних типів рецензій (загалом 76 найменувань) цього науковця за такими ознаками: 1) кількість розглядуваних у ній словників - (а) рецензії-огляди, (б) монорецензії; 2) тип розглядуваних у них словників; 3) мовна характеристика розглядуваних словників; 4) участь або неучасть автора рецензії у створенні рецензованих словників - (а) власне рецензії, (б) авторецензії (Shcherbyn 6).

Данські науковці Х. Бергенхольц і Р. Гууз у статті «Металексикографічний жанр рецензій на словник 3 конкретним посиланням на LexicoNordica та Lexikos» («On the Metalexicographic Genre of Dictionary Reviews, with Specific Reference to LexicoNordica and Lexikos») виділяють шість типів рецензій на неспеціальні словники: 1) коротка характеристика без критичної оцінки; 2) огляд публікації загалом; 3) оглядова стаття, що пропонує багатоаспектну та науково обгрунтовану характеристику; 4) відповідь автора металексикографічної роботи або словника на огляд чи оглядову статтю; 5) експертні оцінки, наприклад, металексикографічні публікації та тези конференцій; 6) оцінка словника або аспектів одного чи декількох словників як частини більшої металексикографічної публікації (переклад автор. - Т. П.) (Bergenholtz 62). 3 визначеним данськими дослідниками четвертим типом рецензії в запропонованому формулюванні - «відповідь автора металексикографічної роботи або словника на огляд чи оглядову статтю» - погодитися важко, оскільки відповідь на критику - це не рецензія, а публікація дискусійного характеру. У цьому разі пропонуємо виокремлювати два типи рецензій: 1) рещензії, що отримали відповідь автора (авторів) словника; 2) рецензії, що не отримали відповіді автора (авторів) словника.

Спираючись на здобутки й досвід українських та зарубіжних мовознавців, а також на власні спостереження й напрацювання, виділясмо типи рецензій на спеціальні словники, запропонувавши їхню багатоаспектну й універсальну типологію за такими ознаками, як: 1) кількість авторів рецензї̈ 2) фах рецензента; 3) тип журналу, у якому вмішено рецензію; 4) обсяг інформації, репрезентованої в рецензії; 5) кількість аналізованих словників у рецензї̈; 6) тип розглядуваних спеціальних словників; 7) стиль викладу тексту в рецензії; 8) час реагування на вихід у світ словника; 9) наявність / відсутність наукової дискусії, тобто наявність / відсутність відповіді на реценнзію.

У цій статті фокус уваги зосередимо на аналізі типів рецензій за останньою ознакою багатоаспектної типології. Так, за наявністю / відсутністю наукової дискусії, тобто наявністю / відсутністю відповіді автора (авторів) словника на рецензію виокремлюємо такі жанрові типи (різновиди) рецензій: 1) рецензії, що отримали відповідь автора (авторів) словника; 2) рецензії, що не отримали відповіді автора (авторів) словника.

Проаналізуймо тип рецензій, що отримали відповідь автора (авторів) словника. Особливості побудови рецензії допускають ведення діалогу між рецензентом та автором (авторами) експертизованого видання. Можливість спілкування як реакція на появу критики словника засвідчує важливу іï функцію - наукову комунікацію, що може набувати ознак дискусії, у ході якої словникарі формулюють відповіді на зауваження, тобто спростовують їх, відстоюють правильність вибору способу репрезентування того чи того словникового параметра та ін. В укладача словника бажання відповісти на критику, тобто вступити в діалог з рецензентом, провокує емоційне тло зауважень і побажань щодо спеціального видання та його компонентів у тексті рецензії або неприйняття критики експерта. Так «зав'язується» фахове спілкування між автором і критиком стосовно термінографічного об'єкта (словника), викликане незгодою укладача з негативним його коментарем, що сприймається як особиста образа, а що гірше - його «дискваліфікація» як словникаря. Відповідно, виникає наукова дискусія, об’єктом якої почасти є вже не стільки первинний текст, скільки рецензія експерта.

Укладачі термінологічних словників поодиноко відповідають на зауваження експертів, тобто не часто продовжується наукова комунікація щодо спеціальних видань. Справді, сьогодні термінографічна критична полеміка втратила свої позиції, здебільшого публічне наукове обговорення чи то суперечки виникають стосовно лексикографічних (загальномовних словників різних типів), наукових (монографій, статей), науково-навчальних (посібників, підручників) видань. Наприклад, на викладені положення й судження в розгорнутій статті д-ра філол. наук В. Німчука «Про сучасну українську тлумачну лексикографію» (2012) реагує д-р філол. наук В. Широков публікацією «Репліка на статтю В. В. Німчука “Про сучасну українську тлумачну лексикографію”» (2013), на яку В. Німчук друкує «Репліка на репліку В. А. Широкова» (2013). Як бачимо, відповідь автора рецензентові «провокує» відповідь на його відповідь і так далі. За спостереженнями авторки цієї розвідки, кількість відповідей у ланцюжку професійного діалогу може становити не більше трьох, найчастіше - одну відповідь. Крім того, якщо сьогодні публікування відповіді на критику словника $\epsilon$ «рідкісним» явищем, то в XIX ст. і на поч. XX ст. це було очікуваною реакцією, але, звісно, виключно на негативну його оцінку. Наприклад, на рецензію М. Цертелєва на «Граматику малоросійського наріччя» («Грамматику малороссийского наречия») i «Короткий малоросійський словник» («Краткий малороссийский словарь», що був надрукований 1818 р. як додаток до цієї граматики) 
О. Павловський публікує 1822 р. відповідь, у якій із сумом визнає, що «втрачає бажання видавати надалі щонебудь важливе» (Pavlovskyy).

Прикладом «запеклого» діалогу є відповідь В. Модестова (1890) на рецензію його книги «Лекції з історії римської літератури» («Лекции по истории римской литературы») (1888) Ф. Зелінським (1889), зокрема предметом дискусії стала відмова рецензента визнати нову працю як наукове дослідження: «Звертаючись до мене й висловлюючи своє внутрішнє невдоволення до мене в настільки образливих висловлюваннях, п. Зелінський бере на себе [...] занадто багато. Він ніби не підозрює, що за це хвилинне відчуття задоволення йому доведеться недешево поплатитися. I справді, якщо я в своїй науці дилетант, то хто ж він, п. Зелінський, що не репрезентував із цієї науки жодної праці й літературним чином до неї абсолютно недотичний? ... що ж сказати про те, що п. Зелінський мені приписує “сумне становище людини, своїми ж не визнаного”? За яким правом він дозволяє собі робити таку заяву? Від імені яких учених він говорить? Хто це, свої, які мене не визнають? ... П. Зелінський порушив питання дуже делікатне [...] я маю право сказати, що мої наукові праці оцінювалися багато разів і в російській, і в зарубіжній пресі, людьми дуже компетентними й дуже відомими [...]» (переклад автор. - Т. П.) (Modestov). Складно назвати цю полеміку науковою чи віднайти в ній конструктивність поглядів, оскільки більшою мірою це прояв образи, «вилив емоцій». Необхідно дотримуватися певних вимог до ведення дискусії та не перетворювати ії на принизливу й беззмістовну сварку.

Загалом українські термінографічні праці поч. ХХ ст. знаходили широкий відгомін у наукових колах. Час від часу у періодиці з'являлися рецензії та критичні публікації, наприклад: М. Гладкий «До проблеми нашої наукової термінології: Російсько-український словник правничої мови» (1926); Г. Холодний «Які мають бути словники Інституту української наукової мови» (1928) та ін. Рецензії містили глибокий аналіз й об'єктивну оцінку праць, пропозиції щодо поліпшення їхньої якості. Зауважмо, що інколи рецензії друкували без зазначення авторства, тобто анонімні, наприклад: у журналі «Комуніст» (№ 22) за 1927 р. опублікована така стаття про «Неусталеність правничої термінології»; у «Віснику природознавства» (Кн. 4) за 1927 р. - «Словник зоологічної номенклатури та термінології»; у «Червоний шлях» (№ 4) за 1927 р. - «Спортовий український термінологічний словник» (Kochan 15). Ці рецензії не спричинили дискусій, утім вони засвідчують неабияке зацікавлення наукового суспільства та фахівців кодифікуванням спеціальної мови та підвищенням якості термінологічних словників.

Х. Бергенхольц і Р. Гууз теж наголошують, що відповіді на критику словника «не зустрічаються часто, але ця категорія є складником словникової критики, яку потрібно розширити, оскільки це сприяє критичному й двонаправленому обговоренню лексикографічних робіт. Автори рецензованих публікацій повинні отримати можливість відповідати на відгуки стосовно їхньої роботи - визнати поради, які вони отримують від рецензентів, та мотивувати деякі свої рішення» (переклад автор. - Т. П.) (Bergenholtz, 2016, p. 63).

Приклад рецензії, що отримала відповідь співавторів термінологічного словника, віднаходимо на сторінках «Вісника Національного університету “Львівська політехніка”», серії «Проблеми української термінології» в 765-му випуску за 2013 р., зокрема одноосібну рецензію В. Моргунюка (Morhunyuk) на створений колективом авторів «Словник-довідник термінології музейництва» (Mykul'chyk Slovnyk-dovidnyk terminolohiyi muzeynytstva), а також колективну відповідь усіх співавторів словника на цю критичну статтю (Mykul'chyk Dekil'ka dumok u vidpovid'...). Дозволимо собі припустити, що факт наявності в одному випуску журналу і рецензії, і відповіді авторів словника на його критику засвідчує, що і рецензент, і укладачі ще до опублікування їхніх статей, обговорили аналізоване видання, висловили свої міркування й позицію стосовно способів і принципів репрезентування терміноматеріалу в ньому, про що потім виклали інформацію у своїх публікаціях. Так, усна наукова дискусія «перемістилася» на друковані сторінки наукового журналу, набувши жанрових форм термінографічної критики. Зокрема, упорядники словника в тексті статті «Декілька думок у відповідь...» зазначають: «Ознайомившись 3 рецензією на “Словник-довідник термінології музейництва” укладачі Словника дякують п. Виталю Моргунюку за зауваги до цієї праці. Думки, висловлені в цій рецензії, є важливими, і їх буде враховано під час роботи над наступною редакцією словника» (Mykul'chyk Dekil'ka dumok u vidpovid'...). Автори словника демонструють повагу й шанобливе ставлення до експерта, про що свідчить використане словосполучення «шановний рецензент», а також прийняття окремого зауваження: «Погоджуючись із рецензентом щодо вживання іменників, які позначають дію, подію й наслідок, укладачі не впроваджували цих термінів з огляду на вищенаведені аргументи». Утім більшою мірою колектив спростовує зауваження рецензента, трактуючи їх як «помилки в рецензії», пов’язуючи це, наприклад, з підміною понять «через те, що рецензент не володіє поняттєвим апаратом музейництва. Прикладом підміни понять є пропозиція замінити стан збереження музейного предмета на стан збереженого музейного предмета (між іншим, рецензент висловлює свої пропозиції в категоричній формі має бути). Ці словосполуки не $\epsilon$ ідентичними». Загалом автори словника врівноважено відстоюють свій вибір принципів репрезентування терміноодиниць, закінчуючи рецензію таким міркуванням: «Укладання цього словника також було спробою привернути увагу музейників і термінологів до проблем термінології музейництва. Судячи з отриманих відгуків, ця спроба вдалася й науковці звернуть увагу на нормалізацію цієї терміносистеми» (Mykul'chyk Dekil'ka dumok u vidpovid'...). Отже, проаналізований тип рецензій є цінним, оскільки він створює комунікативні можливості публічно й відкрито експертизувати словник. Не вважаємо, що поодинокі відповіді на рецензії засвідчують «вимирання» форми наукової дискусії та жанру рецензії загалом, хоча відзначмо, що певні проблеми тут, звісно, існують. Припускаємо, що їхньому розвитку можуть перешкоджати такі чинники: 1) професійна етика; 2) зазначення авторства рецензії, тобто неанонімність, що викликає небажання вступати в гострий конфлікт авторитет- 
них науковців; 3) недостатність «критичної маси» напрацювань метатермінографією стосовно теоретико-методологічних принципів і засад відображення спеціальної лексики в термінологічних словниках, зокрема відсутність інваріантних (уніфікованих) способів репрезентування структурних параметрів термінографічних праць.

Жанровий тип рецензій, щцо не отримали відповіді автора (авторів) словника, посідає панівну позицію в типології рецензій на спеціальні словники. Якщо автор термінологічного словника не відповідає на негативну критику його видання, то це підтверджує його згоду із зауваженнями експерта й зазначеними ним недоліками. Утримання від відповіді укладача словника - своєрідне визнання допущених помилок і неточностей.

Отже, рецензія на термінологічний словник - це (1) експертний висновок якості словника, (2) динамічна, «жива» форма, через яку відбуваються професійний діалог і наукова дискусія стосовно видання. Виникнення наукової дискусії свідчить не про гострий конфлікт між критиком і автором словника, а про небайдужість до якості термінографічної продукції і невпинний пошук інваріантних способів або принципів лексикографічного репрезентування того чи того параметра в спеціальному словнику. Потенційна важливість теоретико-практичного застосування результатів публічного наукового обговорення термінологічного словника полягає в можливості систематизувати виявлені критиками недоліки репрезентування його структурних елементів задля вдосконалення засадничих теоретико-методологічних основ метатермінографії й розроблення інваріантної моделі словника нового типу.

\section{References}

Vakhtyn, Nykolay. Forum o forume (yly o sostoyanyy dyskussyonnoho polya nauky) (Forum about forum (or about the state of science debate field)). Web. 11 Sept. 2019.

Humanenko, Oleksandra. "Osoblyvosti typolohichnoyi kharakterystyky retsenziy na naukovi tvory (Typological characteristic features of reviews of scientific works). Naukovi zapysky 3 (2011): 119-126. Print.

Zelynskyy, Faddey. "Rets.: Modestov V. Y. Lektsyy po ystoryy rymskoy lyteraturb, chytannыe v Kyevskom y Sankt-Peterburhskom unyversytete. Polnoe yzdanye. SPb., 1888 (Rev.: Modestov V. I. Lectures on the History of Roman Literature, given at Kiev and St. Petersburg University. The full edition. St. Petersburg, 1888). ZhMNP 1. 2 (1889): 188248. Web. 03 Sept. 2019.

Kochan, Iryna. Ukrayins'ke terminoznavstvo v imenakh (Ukrainian terminology in names). L'viv: Litopys, 2012. Print.

Mekh, Nataliya. "Zhanrosfera suchasnoyi ukrayins'koyi naukovoyi komunikatsiyi (Genre sphere of modern Ukrainian scientific communication)". Mova i mizhkul'turna komunikatsiya 1 (2017): 64-73. Print.

Mykul'chyk, Roman, Slobodyan, Petro, Didenko, Ye., Rak, T. "Dekil'ka dumok u vidpovid'... (Some ideas in response....)". Visnyk Nats. un-tu "L'vivs'ka politekhnika”. Seriya "Problemy ukrayins'koyi terminolohiyi" 5 (2013): 147148. Web. 28 May. 2019.

Mykul'chyk, R., Slobodyan, P., Didenko, Yelizaveta, Rak, Taras. "Slovnyk-dovidnyk terminolohiyi muzeynytstva (Dictionary of museum terminology)". L'viv: Vyd-vo Nats. un-tu "L'vivs'ka politekhnika", 2012. Print.

Modestov, Vasylyy. "Otvet na retsenzyyu h. Zelynskoho (Response to the review by Mr. Zelinskyi)". ZhMNP 1.2 (1890): 212-230. Web. 4 Aug. 2019.

Morhunyuk, Vytal'. "Retsenziya na «Slovnyk-dovidnyk terminolohiyi muzeynytstva» (Mykul'chyk R. ta in., L'viv: Vyd-vo L'vivs'koyi politekhniky, 2012. 128 s.) (A Review of the Museums Terminology Dictionary, Myckul'chyk R., L'viv: Vyd-vo Nats. un-tu “L'vivs'ka politekhnika”2012. 128 c.))". Visnyk Nats. un-tu “L'vivs'ka politekhnika”. Seriya "Problemy ukrayins'koyi terminolohiyi" 765 (2013): 143-146. Print.

Pavlovskyy, A. P. Prybavlenye k hrammatyke malorossyyskoho narechyya, yly otvet na retsenzyyu, sdelannuyu na onuyu hramatyku (Adding to the grammar of the Malorossiia dialect, or responding to a review made on that grammar). SPb.: typ. Y. Baykov, 1822. Web. 27 Aug. 2019.

Petrova, Tetyana. "Ukrayins'ka terminohrafichna krytyka: vid vytokiv do suchasnosti (Ukrainian Terminographic Criticism: From Origins to the Present)". Naukovyy visnyk Nats. un-tu bioresursiv i pryrodokorystuvannya Ukrayiny. Seriya Filolohichni nauky 292 (2018): 208-217. Print.

Stepanov, Borys. "Kryzys zhanra»: knyzhnыe retsenzyy v perspektyve yssledovanyy nauchnoy kommunykatsyy ("Crisis of the genre": book reviews in the perspective of scientific communication studies)". Laboratorium 8 (1) (2016): 82-106. Print.

Chernyshova, Maryna. "Parametru leksykohrafycheskoy krytyky (Parameters of lexicographic criticism)". Slovo y slovar'. Vocabulum et vocabularium 12 (2011): 7-10. Print.

Shcherbyn, Vladymyr. "Vklad O. N. Trubacheva v razvytye nauchnoy krytyky slovarey (O. N. Trubachov's contribution to the development of dictionaries scientific criticism)". Voprosbl yazblkoznanyya 5 (2007): 3-21. Print.

Yatsenko, Nina. "Zhanrovo-styl'ova spetsyfika naukovoyi retsenziyi (Genre and stylistic specificity of a scientific review)". Ukrayins'ka mova 1 (2017): 92-101. Print.

Bergenholtz, Henning, Gouws, Rufus. "On the Metalexicographic Genre of Dictionary Reviews, with Specific Reference to LexicoNordica and Lexikos". Lexikos 26 (2016): 60-81. Web. 03 Jun. 2019.

Надійшла до редакції 10 жовтня 2019 року. 


\section{REVIEW OF A TERMINOLOGICAL DICTIONARY: EXAMINATION, PROFESSIONAL DIALOGUE AND SCIENTIFIC DISCUSSION}

Tetiana Petrova

The Department of Language Disciplines, Kharkiv National Agrarian University named after V. V. Dokuchaiev, Kharkiv, Ukraine

\section{Abstract}

Background. One of the forms of a scientific discussion is a review. Due to the increasing interest in studing the specifics of holding scientific discussions, more emphasis should be placed on critical sub-discourse, in particular, its genre form - a review - as its main representative.

Purpose. To analyze scientific discussions-dialogues in the texts of articles-responses to reviews of terminology dictionaries, to find out their theoretical and practical significance, to distinguish the corresponding genre types of special editions reviews on the basis of 'presence / absence of scientific discussion'.

Results. The dispute in the text of articles-responses to the review of dictionaries is a discussion-dialogue, a public scientific-critical discussion on the representation features of the special dictionary parameters. Today the terminological critical controversy has lost its position and the compilers of terminology dictionaries individually respond to the experts' comments.

On the basis of 'presence/absence of scientific discussion, that is, presence / absence of the author's (authors') response' we distinguish the following genre types of reviews: 1) the reviews that received the response of the author (authors) of the dictionary; 2) the reviews that has not received the author's (authors') response. The first type of reviews is "rare" and valuable because it creates communicative opportunities to expertize a dictionary publicly. The second type of reviews is the most common. Withholding a response from the compiler of the dictionary is a kind of acknowledgment of mistakes and inaccuracies made, as well as the agreement with the expert's remarks and drawbacks indicated.

Discussion (conclusions and perspectives). A terminology dictionary review is (1) an expert opinion of the dictionary quality, (2) a dynamic, "live" form through which a professional dialogue and a scientific discussion about the publication take place. The potential importance of theoretical and practical application of the results of public scientific and critical discussion of a terminological dictionary is the ability to systematize the drawbacks in representing its parameters which were identified by the critics in order to improve the basic theoretical and methodological foundations of metaterminography and develop an invariant model of a dictionary of a new type.

Key words: critic, science discussion, professional dialogue, review, article-response, terminology dictionary, type of review.

Vitae: Tetiana Petrova, PhD in Philology, Associate Professor at the Department of Language Disciplines, Kharkiv National Agrarian University named after V. V. Dokuchaiev. The areas of research interests include the Ukrainian terminology and terminography, terminographic criticism and language culture.

Correspondence: t-petrova@ukr.net

Ígor Yu. Protsenko

DOI 10.31558/1815-3070.2019.38.14

\section{FACTORES HISTORICOS Y SOCIOCULTURALES DE LA FORMACIÓN DE LA SITUACUÓN LINGÜÍSTICA DEL PARAGUAY}

Розглянуто особливості білінгвізму у Парагваї, наводяться його диференційні риси щзодо подібних феноменів у інших багатомовних краӥнах. Поставлено питання чи на справді можна характеризувати лінгвістичну ситуацію у крахні як білінгвізм, або диглосія. Констатовано використання de fасто справжньої третьої мови Јорага́. Розглянуто вплив історичних, соціально-політичний та культурних факторів на формування самобутності лінгвістичної ситуації у Парагваї. Наводяться приклади своєрідності іспанської мови та мови гуарані у Парагваї.

Ключові слова: білінгвізм, диглосія, «третя мова» Парагваю, семантика, лінгвістичні контакти.

En el artículo se hace el intento de revelar las peculiaridades del bilingüismo paraguayo. Se plantea la pregunta si es bilingüismo o diglosia. Se revela que de facto la situación lingüística del Paraguay se caracteriza por la existencia de la "tercera lengua" del país, Jopará. Se revela la importancia de los contactos culturales, históricos, socio-políticos que influyó de la formación de la situación lingüística actual en el país y el funcionamiento de los repertorios lingüísticos del español y el guaraní en la sociedad moderna paraguaya. Se revelan unas peculiaridades del español paraguayo y el guaraní paraguayo. Se analiza el bilingüismo paraguayo desde varios aspectos socio-culturales.

Palabras claves: bilingüismo, diglosia, guaraní, "tercera lengua” del Paraguay, semántica, contactos lingüísticos.

The article attempts to reveal the peculiarities of Paraguayan bilingualism. The question arises whether it is bilingualism or diglossia. It is revealed that de facto the linguistic situation of Paraguay is characterized by the existence 